\title{
労働災害統計分析研究の変遷に関する研究
}

\section{Historical Review on the Statistical Analysis Research of Occupational Accidents}

\author{
労働省産業安全研究所 花安 繁郎* \\ by Shigeo HANAYASU*
}

\begin{abstract}
建設工事では毎年多くの労働災害が発生しており，これらの災害を防止することは建設 事業を円滑に進める上で重要な課題である。建設マネジメントの中で安全管理は，建設工 事遂行に当たっての重要な管理システムの一つとして位置づけられている。労働災害統計 の調査，分析に関する業務は，災害に関する基礎的情報を提供し，これにより問題点の把 握や安全対策を設定したり，安全研究の方向性を定めるなど，安全管理での意志決定に重 要な役割を果たしている。本研究は，これまで行われてきた労働災害に関する統計学的分 析研究について, 特に確率統計学的分析研究を中心にその歴史的変遷を概括することを試 み, また, その調査結果をふまえ, 今後の労働災害統計分析研究が進むべき方向性とそこ での課題を考察したものである。
\end{abstract}

【キーワード】 労働災害, 安全・衛生管理, 統計分析

\section{1.まえ がき}

土木工事を含め建設工事では毎年多くの労働災害 が発生し, とくに死亡災害では全産業災害の4割以上 を占めている。これらの労働災害の発生を防止する こと，あるいはその被害を低減することは建設事業 を円滑に進めるうえで重要な課題となっている。

建設事業では，プロジェクトの企画段階から維持 管理に至るまで多くの管理システムが運用されてい る。安全管理は，このうち，施丁段階における工事 管理の中で，工程管理，原価管理，品質管理と並ん で重要な管理システムとして位置づけられている。

安全管理とは，災害に係る多くの要因を把握し， 分析・評価を加えたのち，それらを効果的に除去， 制御するために体系だてた管理システムと定義する ことが出来る。この安全管理の中で災害統計に関す る調査，分析の業務は，種々の災害に関する基礎的 情報を提供し，これにより問題点の把握や安全対策 を設定したり，安全研究の方向性を定めるなど，安 全管理での意志決定に重要な役割を果たしている。

＊安全技術課０3-3453-8441，0424-91-4512
労働災害の統計分析には多くの目的と役割が考え られるが，その代表的な項目を挙げると以下のとお クである。

(1)労働災害の発生特性とその原因に関する情報を提 供し，災害発生防止のために，関係行政機関におけ る法律・規則の立案, 行政指導, あるいは研究課題 設定等の参考資料として用いること。

(2)同様に, 個々の企業に扔ける安全対策の立案, 実 施ならびにその評価に利用すること。

(3)労働災害発生危険率などを評価して，峃働災害保 険・労働災害補償制度の健全な運用を図ること。

これらの目的を踏まえ, 今後の災害統計の分析研 究が進むべき方向性と，そこでの課題を明らかにす ることは重要なことと考えられる。そのためにこ れまで行われてきた災害に関する統計学的分析研究 について，その歴史的変遷を概括することは一助に なると考えられる。本研究は，これまで行われてき た労働災害に関する統計学的分析研究について，と くに確率統計学的分析研究を中心にその歴史的変遷 を概括することを試み，また，その調査結果を踏ま えて, 今後の労働災害の統計分析研究が進むべき方 向とそこでの課題を考察したものである。 


\section{2. 労働災害統計分析研究の歴史的変遷}

洋の東西を問わず古来からさまざまな災害が発生 しており,それらのうちの大規模な災害については, その発生状況や被害の模様を記述した記録を多くの 文献・資料等に見ることが出来る。

しかし，災害に関する多くの資料を収集し，それ らを用いて災害の統計学的特性を明らかにする研究 が行われるようになったのは，いくつかの例外を除 くと近代自然科学が成立した18世紀以降である。

特に労働災害のように，18世紀末葉イギリスで始 まった産業革命によって大量の労働者が出現し, 彼 らが労働者階級という新たな社会階級を形成する過 程で顕在化した一種の社会（階級的）災害について は, 当初からその定義, 資料収集法, 評価法等につ いて国ごとに差があり，資料収集が可能となり本格 的な統計学的分析研究が行われるまでにはかなりの 時間を要した。

ここでは，筆者がこれまでに調査した災害統計分 析に関する研究のうちで, 特に確率論的研究を中心 にその変遷について述べることとする。

\section{(1) 災害統計分析研究の発端}

事故や災害の発生状況を統計的に調査・記述した 事例は, 古くは記述統計学研究の嚆矢としてつとに 有名な J. Grauntによる「死亡表に関する自然的お よび政治的諸観察」にも見いだすことができる1)。同 書によれば，17世紀中葉のロンドン市において， 1629～1636年および1647～1658年の 20 年間に疾病や 事故によって229, 250人の埋葬者があったことが記 録されており，そのうち，慢性疾患による病死や溺 死あるいは自殺などと並んで，「種々の事故」による 死者数が毎年の埋葬者の総数に対して恒常的比率を 保っていたことが記されている。

また, Von-Bortkiewicz がプロシヤ軍団内で馬に 蹴られて死亡した兵士数を 20 年間にわたって調べ, その頻度分布がポアソン分布であったこと (1898年) も，事故統計分析の古典的な例としてよく引き合い に出されている2)。

しかしながら, Graunt の事故に関する分析は, 大 量の死亡表を用いてさまざまな社会学的観点から観 察を行った分析結果の一つであって，「種々の事故」
そのものを分析の対象としていた訳ではない。同様 に, Bortkiewiczの分析事例も，馬に蹴られて死んだ という災害事象自体を分析の目的としていたか否か は明らかでない。

災害, 特に工場等で発生する労働災害の発生特性 を解明することを目的とした統計的研究が行われた のは20世紀に入ってからであり，Greenwood -Wood，およびGreenwood-Yule らによる統計学 的研究に始まると言われている。M. Greenwood, H. Wood および G. Yule ら ${ }^{3,4}$ は，第一次世界大戦下の 英国の軍需工場で作業した女子労働者に発生した労 働災害を調査し, その発生特性, 特に作業者の災害 発生の蓋然性（Accident liability）に関して，以下 の三つの仮説的確率分布モデルを導入して考察を加 えた。

\section{i ）偶然分布（Simple chance distribution）}

作業員の災害蓋然性は一様であり，災害は偶然に よって生起すると考え，その理論分布はポアソン分 布になるとした。もし災害発生数分布がこの分布で あれば，発生数を減らすには，個々の作業員の心理 的，生理的な条件を改善するばかりでなく，職場の 物的環境や作業条件などの作業全般状況（General condition）を改善することが主な対策となるとして いる。

ii）偏奇分布 (Biased distribution)

作業員の災害蓋然性は当初は一様であるが，災害 を起こした者は，そのことが原因となって臆病ある いは神経過敏になり，災害蓋然性が以前に比べて変 化し，増加または減少するという仮定のもとで標記 の分布が導出された。もしバイアスが増加（災害を 起こしやすくなる）する方向であれば，对策として は，災害発生後は暫く仕事を休ませる，あるいは短 期間別の仕事に従事させることなどで蓋然性を減少 させる必要があるとした。

iii）非均等分布（Unequal liabilities distribution)

作業員の災害に対する蓋然性は一様ではなく，む しろ作業員ごとに異なった大きさの蓋然性によって 構成されるという考えのもとに導出された。災害全 体の分布は，作業員ごとの発生数分布であるポアソ ン分布と，同分布のパラメータである蓋然性の分布 とを混合した分布となる。当初は蓋然性の分布とし て正規分布を仮定し，ポアソン分布との複合化の手 
続きを経てエルミート分布と呼ばれる分布を導出し たが，災害の起こり易さ（蓋然性）が（－乎０）ま での負の值をとるのは不合理であるとして， $[0 \sim+\infty)$ までの範囲で分布する確率分布のうちで 計算上便利な Pearson III type 分布（ガンマ分布） を新たに採用し，ポアソン分布との複合化を行った 結果, Greenwood-Yule 分布と呼ばれる負の二項分 布に到達した。そして，この仮定のもとでの災害防 止には，災害蓋然性の少ない作業員を選ぶことや， 災害を多く起こした者を早期に除去することが有効 な対策であると想定した。

Greenwood は, 前記軍需工場における14グ ループの作業員が起こした労働災害の発生数分布を 調べた結果，ポアソン分布は適合せず，偏奇分布あ るいは非均等分布（負の二項分布）が良く適合する ことを示した。さらに，観測期間を二分割して前期 および後期の災害発生数の相関係数を求めた結果, 0.4 0.7の間で比較的高い值であること，および， 前期で無災害だった作業員を除外して求めた相関係 数が，全作業員を含めて計算した相関係数よりも小 さいことから，非均等分布の方が偏奇分布よりも事 実をうまく説明していると考え, 最終的に, これら の調査事実をもとに，災害発生数分布を規定する際 には，個々の作業員の災害性向の変動が極めて重要 な因子であると結論づけた。

この研究に続いて, E. Newbold ${ }^{5,6}$ によって多くの 工場における労働災害の調査, 分析が行われた。 Newbold は, 電気機器工場, 織物機械工場, 自動車 工場, 菓子工場, 弾薬工場など, 22 種もの広範囲な 製造工場を選び，そこで動く25の男子作業員グルー プ 6,938 人， 14 の女子グループ 2,024 人が 3 ヶ月〜 3 年の調查期間内に起こした労働災害 16,188 件につい てさまざまな角度から調査し，その結果，

(1)どのグループの災害も少数の作業員によって大多 数の災害が占められており, 災害が作業員間で偶然 に生起しているとは考えられない。

(2) Greenwood らが提案した偶然分布以外の $2 つ の$ 分布のうち，偏奇分布は適合せず，非均等分布がう まく適合した。

(3)異なる調查期間における災害発生数の相関係数が 安定していること（12グループのうち 9 グループま での災害が0.2〜0.6の值を示した)，また異なった種
類の災害との間にも相関関係がみられること, 更に 工場での災害と家庭での災害との間にも相関関係が みられること，などの多くの調査結果から，作業員 個々人に対する詳細な調査や心理学的調査研究を行 う必要があると述べた。

この Newboldによる研究ののち, E. Farmer と E.G. Chamber ${ }^{7}$ は，心理学的試験や生理学的試験の 結果と災害発生との関連をいくつかの業種について 調査, 分析を行い, 運動感覚能力が劣っている者に 災害が多いという統計的関係が存在することを見い だし，この統計的因果特性を表現するために災害頻 発性向 (Accident proneness) という用語を提唱した。 (Accident proneness の訳語として我国では，災害 傾向, 災害頻発性, 災害累発などさまざまな言葉が 用いられているが,ここでは災害頻発性向と訳した）

この災害頻発性向とは, “災害蓋然性よりは狭い内 容を意味し，それを有することによって異常に高い 災害発生率となる傾向を助長する個人的特異性” と 定義され，災害蓋然性が災害発生率を決定づけるす べての要因を含むのに対して，災害頻発性向は作業 員個々人に関連した事柄であるとされた。

また Farmer および Chamber ${ }^{8)}$ は, 自動車事故が ランダムに分布していないことを踏まえて，自動車 運転手を心理・生理学試験の結果を基にいくつかの グループに分けて, 災害と個人の心理・生理学的特 性との関係を明確にする研究を行った。その結果, 運動感覚機能の劣る一部のグループが高い災害発生 率を示すことや，観測期間が長いほどその傾向が顕 著であること，また，多数の災害を起こした者は， その後も高い災害発生率を示す傾向があることなど から，災害頻発性向は災害原因として重要な因子で あり，また，災害の種類や作業条件の如何に拘らず 災害頻発性向は恒常的に存在すると主張した。

Farmer およびChamberによって提唱された Accident proneness は多くの心理学者や生理学者 によって受け入れられ，その後の研究は作業員の身 体的機能や心理的, 精神的特性と災害との関連を探 求することや，災害頻発者を診断するテスト法の開 発に力点がおかれた。

例えば C.S. Slocombe と E.E. Brakeman" ストンの鉄道運輸の運転操作に従事した作業員86人 を災害多発者グループと稀発者グループの 2 群に分 
けて11種類の心理学テストを行った。このうち信頼 性の高かった 7 種類のテストについて，個々のテス トの結果と災害との相関は低かったが，それらを合 計した值との相関は高く，頻発者診断に有効な結果 を得たと述べている。同様に我国においても，災害 発生原因に心理学的側面から検討を加之て，作業員 の災害頻発性向を，さまざまな心理学テストなどを 通して特定する試みが行われた ${ }^{10,11)}$

\section{(2) 災害頻発性向研究の見直し}

これらの研究の多くが，災害頻発性向の存在その ものを認めた上で，各種の心理・生理学的テストの 結果と災害の相関をみるものや，被験者を災害多発 者グループと稀発者グループとに分けてテストを行 い，その結果の差を検定するものであった。しかし ながら，全体として確定的な結論が得られなかった こともあって，やがて災害頻発性向研究に対する再 検討が行われるようになった。

A. Mintz および M.L. Blum ${ }^{12)}$ は, 心理学研究者の 多くが，ポアソン分布との適合度検定を行わないま まに，少数の労働者によって大部分の災害が占めら れていることを根拠に災害頻発性向の存在を主張し ていると指摘した。また，災害発生数の分布が非均 等分布に適合しても，データの全変動の $20 ４ 0 \%$ が 災害蓋然性による変動であり，残りの60～80\%は予 知できない偶然変動であることを分散分析によって 示し, 災害発生要因分析研究の中で災害頻発性向が 過度に強調されていると主張した。

また, 確率分布導出の点からも, 災害頻発性向の 存在が拠り所としている非均等分布 (負の二項分布) が, Greenwood-Yule らによる，ポアソン分布のパ ラメータをPearson III type 分布（ガンマ分布）で 複合化して得る方法以外にも，

(1)出現率が一定の事象のベルヌーイ試行において, 複数個の事象が生ずるまでの全試行回数の分布とし て負の二項分布が得られる。(この場合の分布は, 別 名パスカル分布と呼ばれている。）

(2)いくつかの個体がまとまった集団（集落）の発生 数分布がポアソン分布に従う一方で，各集落内での 個体数が対数分布に従うとき，個体総数の分布は負 の二項分布となる。(クヌーイユモデル)

(3)ある一定の割合で出生したり死滅したりする確率 過程特性を有する個体総数の分布が負の二項分布と
なる。（出生死滅過程）

(4)ポリヤの壳と呼ばれるモデルから導出されるポリ ヤーエッケンベルガー分布の極限分布として負の二 項分布が得られる。

など，負の二項分布は多くの成因を有してることが 明らかにされた ${ }^{13,14,15)}$ 。とくに, 労働災害の統計分析

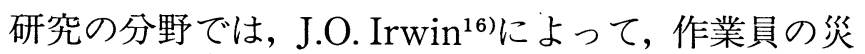
害蓋然性が過去に起こした災害数に一次比例して増 えるという仮定のもとで, 災害発生数の分布が負の 二項分布となることが導かれた。すなわち, Greenwood-Wood らが提案した作業員の蓋然性が災害 によって変化するという第 2 のモデルからでも, 条 件が整えば負の二項分布となることが示された。つ まり, 災害発生数の分布が仮りに非均等分布と呼ば れている負の二項分布にうまく適合しても，そのこ とで作業員間の災害蓋然性が非一様性であること， 更には竾害頻発性向が存在することを証明したこと にならないことが明らかにされた。

これらの結果から，災害頻発性向分析の統計的手 法としては, 従来の 1 変数の分析に加えて, 観測期 間を前後に分割してその相関係数を調べることや， 前期, 後期での災害発生数の分布を 2 変数分布によっ て分析する方法が導入，検討されるようになった。

J.S. Maritz ${ }^{17)}$ は，相関を有する 2 変数ポアソン分 布を用いて災害の分析を行った結果，前期，後期そ れぞれの期間での災害発生数が共にポアソン分布で あっても，2つの期間での災害発生に相関関係が存 在すること, すなわち, 単一期間における発生数分 布がポアソン分布であっても災害蓋然性は一様でな

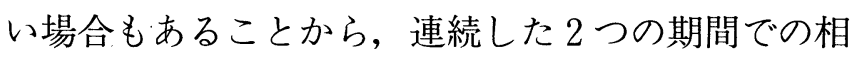
関関係を調べることが重要であると主張した。Maritzは, また, 前期と後期との災害発生数の相関関係 が無相関であっても，各期の災害発生数がそれぞれ 負の二項分布となる場合もあることも示した。

また A.G. Arbous と J.E. Kerrich ${ }^{18)}$ は，観測期間 を 2 分割して災害発生数の変化を調べたところ, 前 期で災害が多い作業員が後期でも多いとは限らない ことや，あるいはその逆の場合もあり，これら前期， 後期の災害発生数を同時に分析するためには二次元 分布による分析が必要であることを述べた。彼らは まず，ポアソン分布と Pearson III type 分布とを複 合化して負の二項分布を得る手法を 2 変数に拡張し 
て 2 変数負の二項分布を導出したのち, 実際に発生 した災害（1937～1947年の11年間に南アフリカ共和 国の鉄道会社の鉄道操車係 112 人が起こした災害 274 件）を，前期（1937〜 1942年の 6 年間）と後期 （1943～1947年の 5 年間）とに分けて分析を行った。 その結果， 2 変数負の二項分布がこれらの災害デー 夕にうまく適合していることや，同分布式のパラ メータを用いて，ある特定件数の災害を起こした作 業員の災害蓋然性の信頼区間を $\chi^{2}$ 分布によって推 定する方法を示した。

また彼らは, Irwinによって示された, 災害蓋然性 が災害発生数に一次比例するという仮定（伝播性モ デル）のもとで，災害発生数が負の二項分布となる 過程を 2 変数の場合にも適用し，同じく 2 変数負の 二項分布に到達することを示した。そして，伝播性 モデルにおける仮定（作業員が職場に長くいて災害 を起こせば起こすほど，益々蓋然性が増えて次の災 害を起こしやすくなるという仮定）が，実際面では 不合理であるにも拘らずデータにはうまく適合して いることから，たんに確率分布への適合結果のみで もとの仮定を主張するのは危険であると指摘した。

Kerrich らは更に Greenwood らが提唱した第 2 のモデル，すなわち作業員の災害蓋然性が災害履歴 によって変化するモデルについても検討を加え，作 業員が一度災害を起こすと，そのことによって作業 を慎重に行う結果, 以降の災害蓋然性が減少すると いう，通称“熱物懲りモデル (burnt finger model)” と呼ばれる仮説的モデルを提案し，同仮説のもとで 災害発生数の分布式を導出し，いくつかの災害事例 に適用して比較的良い適合結果を得ている。

また A.G. Arbous と H.S. Sichel ${ }^{19)}$ は, 労働者の欠 勤デー夕を分析する手法として 2 変数負の二項分布 を利用し，観測期間が同じ長さの連続した $2 つ の$ 期 間での欠勤者数の分析を行った。分析では二次元分 布の評価に加えて, 前期と後期との欠勤者数の相関 係数，および 2 変数負の二項分布のパラメー夕を用 いて前期の欠勤者数に対する後期の欠勤者数の回帰 式を求め, 前期の欠勤者数を説明変数として後期の 欠勤者数を推定する試みを行った。

一方，異なった期間での災害発生数や，質や内容 の異なった災害との間の相関関係などを調べて，災 害頻発性向を分析した研究の代表的なものとして,
A.M. Adelstein による南アフリカ共和国の鉄道会 社での操車係作業員が起こした労㗢災害を分析した 研究がある20)。(前述の Arbous, Kerrich らによる 2 変数負の二項分布を用いた分析では, Adelstein が 集収した災害デー夕の一部が用いられた。）

Adelstein は，1943 1947年の 5 年間に 1,442 人の 作業員が起こした 1,452 件の労働災害に加えて, 上記 作業員が仕事を終え家庭に戻ってから起こした家庭 内災害 (Home injuries, 同じ 5 年間で315人, 173件) および，業務中に発生した災害で作業員が負傷はし なかったが脱線事故や車軸破損などの物的損害を生 じた災害の，3 種類の質の異なった災害デー夕を収 集して分析を行った。分析ではさまざまな集団の災 害発生数の分布と, ポアソン分布あるいは負の二項 分布との適合性を検討したほか，同一作業者による 異なった期間での災害発生数の相関関係, 同一作業 者の業務上での災害と業務外災害（家庭内災害）と の関連, 業務上の負傷災害と物損災害との関連など, さまざまな相関関係の検討を加えた。これらの分析 結果より,

(1)まず，災害発生数の分布適合性に関しては，多く の作業員グループの災害発生数が, 単独にポアソン 分布と，あるいはポアソン分布と負の二項分布とに 同時に適合し，負の二項分布（非均等分布）のみに 適合した例は，1937～1947年まで11年間の長期間に わたって発生した災害や，物的損害を生じた災害に 限られた。

(2)一方，相関関係での分析でも，重傷災害（休業 7 日以上の労働災害）と軽傷災害（休業 6 日以下の災 害) との相関 $(\gamma=0.102)$, 家庭災害と労働災害との 相関 $(\gamma=0.18,-0.03)$, 負傷災害と物損災害との相 関 $(\gamma=0.03)$ など, 質や種類の異なった災害との間 では明確な相関関係を見出すことが出来ず，また， 同じ災害について観測期間を分割し，前期と後期と の間での相関関係を調べても有意な関係を検出する ことが出来なかった。(比較的明確な相関関係がみら れた例としては，負傷災害と病気との関連，および 物損災害が時系列的に安定した相関関係を有してい ることなどをあげている。）

(3)更に，最初の年に高い災害発生率を示した作業員 を除き，翌年以降の災害発生率の変化を調べたとこ ろ, ハイ・リスクグループ作業員を含めた全体の災 
害発生率とほとんど差がないことも明らかにした。

これらの広範な分析結果より, Adelstein は, 従来 からの災害頻発性向に対する解釈，すなわち各個人 は作業環境条件の如何に拘らず一定で，かつ安定し た災害頻発性向を有していると言う考え方に対し て, 新たに, 労働者の災害頻発性向は普遍的で一貫 性を有した因子（General and consistent factor） ではなく, 仮りにそれが存在するにせよ, 偶然性が 災害発生の支配的要因であり, 災害頻発性向は実際 には重要な因子ではなく, かつ特定環境のもとで作 用し, 作業員の日々の活動に伴って変動すると主張 した。

P. Froggatt と J.A. Smiley ${ }^{21}$ は，災害頻発性向に 関する研究についてレビューを行い，それまでの Mintz, Arbous あるいは Adelstein ら多くの研究者 による古典的な災害頻発性向の考え方への批判と, それに基づく修正的な考え方がおおよそ次の 3 点に まとめられると述べている。

(1)災害デー夕によって観測される災害頻発性向は, 労働者が職場で作業に従事した時間の経過に応じて 変動する。

(2)災害頻発性向は, 災害を多発するほんの僅かな限 られた人によって構成され，観測する時期や期間に は依存しない。

(3)災害頻発性向は固定的・安定的な実体でなく, 作 業員ごとに異なり,かつ時間経過とともに変動する。

W.L. Cresswell と P. Froggatt ${ }^{22)}$ は，これらの修 正的な考えを勘案し, 古典的災害頻発性向説に代わ るモデルとして，新たに“spell model”と呼ばれる 仮説を提唱し, 同仮説のもとで災害発生数の確率分 布と実際の分布との比較を試みた。

この spell model とは，災害はまず各作業員が災 害を起こしやすい状態となるある特定の作業時間帯 (spell: periods of time) の中で発生し，その作業時 間帯の中で災害は一定規則に従って起こるという考 え方で, spell 自体の分布も, また spell の中で発生 する災害も共に稀な事象であり，かつ，それぞれが 偶然によって生じると仮定している。更に, 作業員 の spell の起こり易さはどの作業員も等しく, また spell が起こった作業員の spell 内での災害発生に 対する蓋然性も，同じくどの作業員についても等し いと仮定した。このモデルにおける災害発生数の分
布は, ランダムにポアソン分布に従って生起する spellのもとで, 各 spell 内でこれまたポアソン分布 に従って発生する災害数の分布を考えれば良く，確 率分布としては, J. Neyman が1939年に導出した Neyman type A 分布となるが23), spell model のも とでは，同式は“Long”分布と呼ばれている。

また彼らは,この spell model を更に拡張して, 災 害が前述の spell 期間以外にも (ランダムに) 発生す る場合を考え, Long 分布とポアソン分布とをたた み込んだ 3 パラメー夕を有する “Short” 分布と呼ば れる新たな確率分布を導出した。C.D. Kemp ${ }^{24)} は$ こ の Long およびShort 分布についての期待值や分散 などの確率分布特性と，分布式の計算を容易にする ための漸化式（Recurrence relationship）や，パラ メー夕を推定するための最尤連立方程式などを導出 した。

Froggattら ${ }^{25,26)} は$, spell modelによるLong お よびShort 分布を，ポアソン分布や負の二項分布な ぞと共に，災害統計以外にも，例えば会社での欠勤 者数やアイルランド, ベルファスト市内での病院来 訪者数（1962～1964年での2,810名の女性患者を調 査）などの分析にも適用した。そして，災害を含め たこれらの事象が，単一の分布式によって説明され ることは余りなく，仮りにうまく適合してもきわめ て限られたデータであることから, 災害頻発性向が 限られた作業員に作用するにしても，一般には固定 的なものではないと結論づけた。

ところで，J.O. Irwin²)は，Froggattらの spell modelによるLong（Neyman type A）分布が, spell model に基づかずとも, 作業員の災害蓋然性が ポアソン分布に従うと仮定して，災害発生数分布の ポアソン分布と災害蓋然性の分布とを複合化するこ とによっても得られることを示した。つまり spell model が災害頻発性向モデルと本質的には差がな いこと，および, 頻発性向モデルが有する困難性(同 一分布がいくつもの成因によって導出されること） を克服するものではないことを明らかにした。

C.D. Kemp ${ }^{28)}$ は，Greenwood から Froggattに至 るまでの災害頻発性向に関連した研究を概括して, それまでの研究が,

(1)災害防止という実用的観点からは，災害頻発性向 と言う概念はほとんど役に立つことはなかった。 
(2)しかし一方で, 確率統計理論という観点からは, 興味のある，かつ他の分野にも有用な多くの成果を 生み出すことが出来た，とまとめている。

また，災害分析研究について人間工学的観点から 広範なレビューを行った J.Surry ${ }^{29}$ は，災害頻発性 向分析研究について次のように述べている。

(1)通常の統計分析によって災害頻発性向を特定する ことは極めて困難であり，

(2)災害頻発性向が仮りに存在するにしても，それは 個人ごとに時間と状況とに応じて変動し，かつその 変動は, 若年層や老年層, 未経験層, あるいは薬中 毒者や酔っぱらいなどの災害蓋然性が高いことによ る変動とは別個のものであること, 従ってその予測 は困難であり，また予測しても信憑性の少ないもの であること，そして，

(3)災害頻発性向が仮りに存在するにせよ，限られた 僅かな数の災害多発者を示すものであり，災害発生 者の大多数の要因は偶然によるものであり, 次いで 危険作業環境によるもの，そして少数の者が未経験 とか高齢化などによる災害蓋然性の差によって災害 を起こし，残りのほんの少しが災害頻発性向による 者であろうと述べている。そして Accident proneness (災害頻発性向)のように䛊用, 乱用されがちな キャッチフレーズを災害分析の分野では用いないこ とが賢明であると結んでいる。

また, ヒューマンエラーの発生率を予測する手法 (THERP)の開発で著名な A.D. Swain ${ }^{30)} は$, 災害防 止のための手法として二つの対照的なアプローチ法 について検討を加えた。一つは，労働者を安全に作 業するように動機づけたり，あるいは災害蓋然性の 高い作業者を見つけ出して排除する方法（作業員の 動機づけによるアプローチ）であり，他は災害防止 の義務を個々の作業員に負わせるのではなく，むし ろ災害蓋然性の高い作業状態を検出し，それらを除 去することによってより安全な作業状態（Safety prone work situation) に改善させる方法（作業状 態の改善によるアプローチ) である。Swainは, こ の二つの方法を比較して，作業者の安全に対する動 機づけは重要であるが，そのことによる作業の改善 の度合は過大評価されているきらいがあり，また災 害頻発性向者を特定する方法も多くが不適切である ことなどから, 災害防止のための努力の主力は, 災
害発生の蓋然性が高い状態（Accident prone situation）を同定し，その改善を図る手法の方がより合理 的かつ有効であると述べている。

以上述べたように, Greenwood, Woodおよび Yule に始まる労働災害の統計学的分析研究は, 災害 頻発性向という人工的な統計上の概念を機軸にして さまざまな発展がみられたが, 災害頻発性向そのも のについては, その実体の不明確さ, 各種統計的分 析法による弁別の困難性, 災害発生への寄与の不確 実さ（仮りに存在するものとしても）などから，災 害因子として大きく取り上げるのは得策ではなく， また取り上げる場合には細心の注意が必要であるこ と, などが多くの研究者の一致した見解として今日 に至っている。

\section{（3）災害頻発性向研究以外の統計分析研究}

これまで述べてきた，災害頻発性向という，いわ ば作業員個々人に関する心理的・生理的特性を確率 統計理論を基調にして調查, 分析を行う研究の流れ とは別に，労働災害に関する広範な災害デー夕の分 析を行い，そこでの共通的，普遍的な統計特性を解 明する研究も行われていた。

我国では, 若命 ${ }^{31}$ が昭和 10 年代後半に, 労働災害に 係る医学的, 心理的要因以外の社会的契機 (医学的, 心理的契機が主観的与件であるのに対して，災害に 対する客観的与件を指す：若命による定義）に関す る災害統計分析研究の必要性を述へ，この分野での 先駆的研究を行った。若命は, 経営の立場から災害 統計を構成するに当たり, 災害という一種の社会科 学的集団の特性を把握するために, 社会的契機の標 識を以下のように分類した。

1 ）人間固有の標識（男女別，年齢別など）

2 ）労働者として社会関係におかれた人間の標識 （勤続年数別，職種別など）

3 ）作業, 作業環境, 産業および産業環境の標識 （産業別分類，工種別分類など）

4）災害の時間特性を表す標識 (時間別, 曜日別, 月別, 季節別, 年別など)

5 ）災害の契機を示す標識（原因別分類）

これらの分類に従い，例えば，年齢別に分類した 工場での工員在籍者数と災害数に強い相関があるこ とを明らかにするなど，さまざまな分析を行ってい る。時あたかも戦時統制下にあり, 安全衛生に関す 
る活動には多くの困難が伴い，また工場監督年報な ど公的な災害統計資料刊行物も次々と廃刊に追い込 まれていった状況下にありながら，いくつかの工場 の助力のもとに得られた災害統計デー夕を頼りに粘 り強い研究を行った努力には感嘆する他はない。

なお，我が国において，統一化された様式の災害 報告のもとで全国的に労働災害（工場災害）が取り まとめられ，かつ災害原因分類が行われるように なったのは，改正工場法が施行された大正15年（昭 和元年) 以降のことである ${ }^{32)}$ 。

また米国においても，大量の労働災害データの統 計分析によって災害の共通，普遍的な統計特性を解 明する研究が行われ，その代表的な研究が保険会社 技師 H.W. Heinrichによってなされた。

H.W. Heinrich は，著書 “Industrial Accident Prevention”において，産業安全に関する一連の原 理・法則を提唱した ${ }^{33)}$ 。この中でとりわけ有名なもの は, 災害発生に関するドミノ連鎖モデルと, 災害によ る被害の程度を分析し, 重傷災害と軽傷災害との発 生比率の関係を明らかにした1:29:300の法則である。

ドミノ連鎖モデルとは，(1)労働災害（Industrial injuries）は事故（Accidents）によって生じ，(2)事 故は（a）人間の不安全行動または（b)不安全な状 態への曝露によって引き起こされ, (3) 不安全な行動 または状態は人間の誤り（Faults）によって発生し, (4)人間の誤りは家系的な性質や社会的環境によって 生ずるという，一連の因果関係を有し、愍害要因が 連鎖（Chain of event）となって災害が発生すると いう考え方である。この因果律要因連鎖モデルは, 災害分析手法に関する方法論として先駆的な役割を 果たし，その後さまざまな修正が加えられたのち多 くの災害事象記述モデルを産み出している。

また，当初は米国軍事産業に始まり，その後航空 宇宙産業，原子力産業などの大規模システムにおけ る事故解析手法として開発され，今日では化学装置 産業を始め一般産業にも普及, 展開している, FTA (Fault Tree Analysis), ETA (Event Tree Analysis), CTA (Causal Tree Analysis), MORT (Management Oversight Risk Tree Analysis) あ るいは GERT (Graphical Evaluation and Review Technique) などによるシミュレーション分析など, いわゆるシステム安全解析手法 ${ }^{34-39)}$ も，ドミノ連鎖
モデルをその源流とみなすことが出来る。

また1:29:300の法則とは, 同一人物が起こした同じ 種類の330件の焱害のうち，300件は無傷で，29件は 軽い傷害を伴い， 1 件が重傷災害であるという，人 的被害の大きさとその発生頻度の関係を示した法則 である。

同様に1:10:30:600の発生比率が, Heinrich の弟子 である F. Bird Jr. らにより175万件の災害デー夕分 析から得られている40)。これは 1 件の重傷または疾 病を伴う災害に対して，10件の軽傷災害，30件の物 損災害および600件の傷害あるいは物損の無い災害 が起こっているという統計的法則性である。

これらの法則の意味するところは，一つの重傷災 害が発生する裏には，その数十倍，数百倍もの小さ な災害があるので，災害防止という観点からは，そ れら軽微な災害や，背後でそれらの発生の源になっ ている不安全行動や不安全状態の発生を予防するこ とが重要であるということにある。

これらの法則は, 労働災害という限られた災害分 野についてであるが，災害による被害の規模とその 発生比率との関係を実証的・定量的に明らかにした 初めての分析事例であり，今日広まりをみせつつあ るリスクアナリシス ${ }^{41,42) の さ き か ゙ け と み な す こ と か ゙ ~}$ 出来る。

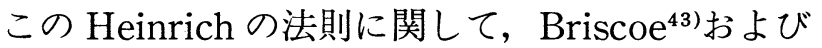
中村44) は, 災害による被害規模分布をべき関数で表 現することを提案し，とくに中村は，被害規模をべ き関数で表したとき，被害規模一発生頻度の関係が 両対数紙上の直線として表現できること，およびそ の傾きが大規模災害発生の潜在的危険性を表す指標 として利用できることを述べている。同様に, 関根 $ら^{45)}$ は, 災害発生数とその被害の大きさとの関係, す なわち災害の階層構造についてフラクタル理論の立 場から分析を加えた。そして，ハインリッヒの法則 で示される災害事象生起則には，フラクタル理論で 取り扱われる自己相似性およびスケーリング則と共 通した特性を有していることを示すと共に，災害規 模と発生数の両対数紙上でのグラフの傾きがフラク タル次元であることを示した。さらに，このフラク タル次元は大規模災害の起こり易さの難易を示すこ とから，対象システムの安全性を定量的に示す統計 的指標として利用できると述べ，火災保険デー夕を 
用いて指標と安全管理機能との関係の分析を試みて いる。

また花安 ${ }^{46,47,48)}$ は，我国の建設工事で発生した労 働災害の分析を行い, 発生数分布の多くがポアソン 分布に従い，また被害規模分布がパレート分布であ るので，労働災害についてもフラクタル理論が適用 できることを示した。そして，近年の建設工事労働 災害は，その頻度，被害強度・規模ともに一定の統 計則に従い，統計的にはほぼランダムに近い状態で 発生していることを明らかにし，これらの分析結果 から，災害防止のためには，単独で大きな効果を期 待できる対策は存在せず，建設工事に係る企画，設 計，施工，運用の建設事業全般を通した広範な建設 マネジメントとしての安全対策を実施することが必 要である述べている。

このほか，例えば ILO（国際労働機関）によって 採択され, 昭和 48 年より労働省の災害分析法として 利用されている, 不安全行動一不安全状態による分 析法や，川崎・田坂・安井による土木工事災害分析 例49)など，いくつかの代表的な災害分析法について は文献50)にコンパクトにまとめられている。

ところで, 災害頻発性向という特殊で限定的な人 的要因の災害への関与については，多くの研究者が 否定的見解に達したことは既に述べたが，人間と災 害の関連そのものが否定された訳ではない。むしろ 産業施設，構造物のように，計画，設計，施工（製 造), 運用など多くのシステムが存在し，それらに人 間の要因が重畳されて影響を与える結果, 構造物等 の破壊や機能不全の原因は, 人間挙動に関する要因, とくにヒューマンエラーが支配的な役割を果たして いると報告されている51)。

山本 ${ }^{52)}$ は, 構造物の安全性を評価するためには, 上 記の各段階でのヒューマンエラーの影響を考慮する 必要があることを述べ，ヒューマンエラーを考慮し た構造物の破壊確率を求めるモデルを提案してい る。分析モデルでは，ヒューマンエラーを考慮した 構造物の破壊確率を求めるために，ヒューマンエ ラーを考慮しない破壊確率を修正する係数（七ュー マンエラー係数）を導入し，土留め支保工に関する 事例分析の結果, ヒューマンエラーを考慮した破壊 確率は，考慮しないそれの $2 \sim 5$ 倍になることを示 している。
また鈴木ら ${ }^{53)} は ， \mathrm{RC}$ 構造物の施工における人為 的過誤が構造物の安全性に及ぼす影響を検討するた めに，人為的過誤の起こり易さは構造物建設の品質 管理と相関があると仮定し，構造物の破壊確率モデ ルを提案している。モデルによる分析から，構造物 の破壊確率は作用荷重の変動係数が小さいほど人為 的過誤の影響を強く受け安全性が損なわれ易いこと や，所定の安全水準を確保するために必要な安全率 は，品質管理の差の影響を受けることを人為的過誤 を考慮したモデルによって明らかにしている。これ らの研究は，設計段階から構造物の安全性を考慮す る際に参考になると思われる。

\section{3.むす び}

以上，労働災害の統計分析研究に関する流れを， 確率論的立場から災害頻発性向を分析した研究を中 心に述へ，また Heinrich 以降の分析研究について も簡単に触れた。これまでの調査で明らかにしたよ うに，労働災害の統計分析研究の流れは主として， (1)作業員の心理的・生理的要素が災害発生の主な要 因と考える研究（行動規範型モデル）

(2)災害は人間，機械および周辺環境の要素で構成さ れるシステム内で生ずる一つの状態であり，これら の要素とその結びつきを変えることにより災害発生 確率も変動すると考之る研究 (状況規範型モデル) という2つの考え方を基調に展開してきている。

今後の研究の方向性は, (1)での作業員固有の心理 的，生理的要因と災害との関わりの研究よりも，人 問を含めた多くの要因と災害しの相互関係（時間の 変動も考慮した）を明らかにし，その知見を災害防 止や被害抑制に結び付けてゆく(2)の考之方の災害分 析研究に力点をおくべきと考える。

また，これまでの災害統計分析，とりわけ災害頻 発性向に関する研究が災害防止には役立たなかった ことが少なからず指摘されているが，これは統計学 に対する認識の差による処が大きいと考えられる。 まえがきにも述べたとおり, 確率統計分析研究の役 割は，事業所における災害実態とその構造を明らか にし, 安全管理等における意志決定のための情報を 提供することにある。従って, 災害統計分析研究そ のものが，例えば安全へルメットや安全ネットに関 
する構造特性研究のように，個々の災害防止に直接 寄与する訳ではない。統計分析研究は，あくまでも 災害のように不確定要素を含んだ未知の事象に対し て合理的な意志決定を行うための論理的枠組みと思 考形成を支援するための方法論であることを指摘し ておきたい。ともすれば災害防止の目的とその手段 が混同されることがある。

本調査結果を踏ま之, 労働災害の統計分析研究に おける今後の課題には以下の項目が考えられる。

（1）災害情報の収集・整理の高度化に関する研究

まえがきにも述べたとおり，事業所におけるさま ざまな災害要因を把握することは, 安全管理活動を 実施する際の基礎となるものである。労働災害に関 する事例は，当該災害の発生原因や発生に至った状 況，およびその防止対策についての情報を提供し， 以降の類似災害の発生防止や被害抑制対策設定に際 して貴重な資料となるのみならず，広く安全技術の 向上に大きな役割を果たすと考えられる。とりわけ 安全教育では，災害事例を用いた教育が，作業員の 安全意識高揚に大きな効果が有るとされている。

従って，各種災害に関する情報を収集したのち， これらをデータベース化し, 必要とする災害情報を 効率的に探索，抽出できるシステムの開発と充実を 図ることが重要である。

安全・災害・事故に関するデータベースは，既に いくつか構築され供用に付されているものもある。 I,かに, 尒国規模での労働災害のデータベースは, 未だ試行的に作成されている段階である ${ }^{54,55) 。 フ ゚ ラ ~}$ イバシ一や企業機密などの多くの制約事項がある が, これらの問題点を克服して大規模な労働災害 データベースの構築が望まれる処である。

鈴木 ${ }^{56)}$ は, データベース構築に当たっては, データ ベースがトップマネジメントレベル，本支店・事業 所レベル，作業単位レベル，作業者個人レベルに階 層化され，かつ各レベルでの安全活動におけるPDS (Plan-Do-See) サイクルの各々のステップで要求 される情報を手際よく提供し，各活動サイクルを効 率的に回転させるものであることが必要であると述 べ，そのための開発プロセス手順を示している。

同じく鈴木 ${ }^{57}$ は，ある年の建設工事死亡災害 $(807$ 件）の発生状況を記述したテキスト資料をデータ ベース化したのち，記録資料に用いられているキー
ワードを分析した結果，1）キーワードの出現頻度 がジップの法則（またはブッラドフォードの法則） に従うこと, 2 ) 少数の高頻度キーワード(上位 $3 \%$, 293種類)が約半数の事例に用いられ，これらのキ一 ワードで災害の種別を高い確率で弁別出来ることな どを明らかにしている。これらの知見は，効率的に 災害事例検索を行う際や，限られたスペースでいか に効率よく災害情報を記述すべきかに当たって有益 な示唆を与えている。

（2）災害情報解析に関する研究

技術者, 安全担当者や作業員などの知識や，デー タベース化された災害情報を利用して災害要因が把 握された後のステップとしては，要因に基づいた災 害がどの程度の頻度で発生するか, 他の要因とどの 様に関連しているか，更にその結果としてどの程度 の被害が予想されるかなど，災害の統計的特性，発 生プロセスの分析，災害発生予測など，災害情報に 関する広範な分析・評価を行うことが必要である。

本論で概括したさまざまな分析手法が，ここで適 用される。例之ば，災害の要因，原因 (Cause) がど のような過程を経て結果 (Accident consequence) に至ったかを記述する災害シナリオをいくつかにパ ターン化し, FMEA 分析やFTA 分析の基礎資料と すること，あるいは，災害シナリオのどの部分を制 御, 管理すれば効果的に発生防止や被害防止につな がるかを解明する研究などが考えられる。

（3）安全管理システムの高度化に関する研究

災害情報を利用した安全管理における次の検討項 目としては，災害情報解析で得られた結果を利用し て，災害発生防止や被害抑制のための活動を効率的 に行うために，安全管理支援エキスパートシステム や安全教育支援プログラムを開発し，安全管理シス テムの高度化を図ることが重要と考えられる。

情報解析での結果をコンピュター化し, 現場での 安全管理活動を支援するシステムの開発と，そのた めの組織体制の整備が重要と考えられる。

これらの災害データベースや分析システムを個々 の事業所で保有することは困難と思われるので, 本 社，支店あるいは第三者機関などのシステムとコン ピュータネットワークで結び, 適宜必要とする情報 を入手できるシステムの構築が期待される。 


\section{【参考文献】}

1）ジョン・グラント：死亡表に関する自然的及び政治的 諸観察，(久留間鮫造訳，高野岩三郎校閲，大原社会問 題研究所編, 統計学古典選集 第三卷) 栗田書店刊, pp.109 114, 1941.

2 ）統計学辞典：東洋経済新報社, pp.974 975, 1989.

3 ) M. Greenwood and H.M. Wood: The Incidence of Industrial Accidents upon Individuals with Special Reference to Multiple Accidents, 1919, In: W. Haddon Jr., E.A. Suchman and D.A. Klein, Accident Research, Harper and Row, New York,pp.389 396, 1964 (Reprinted from Report No.4, 1919, Industrial Fatigue Research Board, Medical Research Committee, Great Britain)

4) M. Greenwood and G.U. Yule: An Inquiry into the Nature of Frequency Distributions Representative of Multiple Happenings with Particular References to the Occurrence of Multiple Attacks of Disease or of Repeated Accidents, J. of Roy. Statis. Soc., Vol. 83, pp.255 279, 1920.

5 ) E.M. Newbold: A Contribution to the Study of the Human Factor in the Causation of Accident, 1926, In: W. Haddon Jr., et al, Accident Research, Harper and Row, New York, pp.398 410, 1964 (Reprinted from Report No.34, 1926, Industrial Fatigue Research Board, Medical Research Committee, Great Britain)

6) E.M. Newbold: Practical Applications of the Statistics of Repeated Events Particularly to Industrial Accidents, J. Roy. Stat. Soc., Vol.90, pp.487 —547, 1927.

7 ) E. Farmer and E.G. Chamber: A Psychological Study of Individual Differences in Accident Rates, Medical Research Council, Industrial Fatigue Research Board, Report No.38, 1926.

8 ) E. Farmer and E.G. Chamber : A Study of Accident Proneness among Motor Drivers, 1939, In: W. Haddon Jr.,et al, Accident Research, Harper and Row, New York, pp.411 417,1964 (Reprinted from Report No.84,1939, Industrial Health Research Board, Medical Research Council, Great Britain)

9 ) C.S. Slocombe and E.E. Brakeman: Psychological Tests and Accident Proneness, Briti. J. of Psychol., Vol.21, pp.29 38, 1930.

10）桐原葆見 -上野義雄：産業安全, 労働基準全書第 3 卷, 東洋書館, pp.301 310, 1948.

11）青島賢司：安全管理者のための安全管理学,オーム社, pp. 68 76, 1973.

12) A. Mintz and M.L. Blum: A Re-examination of the Accident Proneness Concept, J. of Applied Psychology, Vol.33, No.3, pp.195 211, 1949.

13) F.J. Anscombe: Sampling Theory of the Negative Binomial and Logarithmic Series Distributions, Biometrika, Vol.37, pp.358 382, 1950.

14）増山元三郎：少数例のまとめ方 II, 竹内書店新社, pp.590 595, 1976.

15）印東太郎：確率および統計, コロナ社, pp.104 113, 1967.

16) J.O. Irwin: Discussion on Chamber and Yule's Paper, J. Roy. Statis. Soc., Vol.7, pp.101 109, 1941.

17) J.S. Maritz: On the Validity of Inferences drawn from the fitting of Poisson and Negative Binomial Distributions to Observed Accident Data, Psych. Bull., Vol.47, pp.434 443, 1950.

18) A.G. Arbous and J.E. Kerrich: Accident Statistics and the Concept of Accident Proneness, Biometrics, Vol.7, pp.340 432, 1951.

19) A.G. Arbous and H.S. Sichel: New Techniques for the Analysis of Absenteeism Data, Biometrika, Vol. 41, pp.77 90, 1954.

20) A.M. Adelstein: Accident Proneness, A Criticism of the Concept Based upon an Analysis of Shunters' Accidents, J. of Roy. Statis. Soc., Series A, Vol.115, pp.354 410, 1952.

21) P. Froggatt and J.A. Smiley: The Concept of Accident Proneness, A Review, Brit. J. Industr. Med., Vol.21, pp.1 12, 1964.

22) W.L. Cresswell and P. Froggatt: Accident Proneness, or Variable Accident Tendency?, J. Stat. Soc. Inq. Soc. Ireland, Vol.20, No.5, pp.152 171, 1962.

23) J. Ncyman : On a New Class of "Contagious" Distributions Applicable in Entomology and Bacteriology, Ann. Math. Statist., Vol.10, pp.35 57, 1939.

24) C.D. Kemp : On a Contagious Distribution Suggested for Accident Data, Biometrics, Vol.23, pp.241 $\sim 255,1967$.

25) P. Froggatt: One-Day Absence in Industry, J. Stat. Soc. Inq. Soc. Ireland, Vol.21, pp.166 178, 1965.

26) P. Froggatt, M.Y. Dudgeon and J.D. Merrett: Consultations in General Practice Analysis of Individual Frequencies, Brit. J. Prev. Soc. Med., Vol.23, pp.1 $\sim 11,1969$.

27) J.O. Irwin: The Personal Factor in Accidents, J. of Roy. Statis. Soc., Vol.127, pp.438 451, 1964. 
28) C.D. Kemp : "Accident Proneness" and Discrete Distribution Theory, Random Counts in Scientific Work, Vol.2, Penn. State. Univ. Press., pp.41 64, 1970.

29) J. Surry: Industrial Accident Research, A Human Engineering Appraisal, Labour Safety Council, Ontario Ministry of Labour, pp.154 169, 1971.

30) A.D. Swain: The Human Element in Systems Safety, Industrial and Commercial Techniques LTD, 1976.

31）若命鋭一：産業災害の統計的研究，東洋書館，1944.

32）花安繁郎：我国における労働災害統計資料整備の変遷 と災害指標の国際比較に関する調査研究, 労働省産業 安全研究所究報告, RIIS-RR-90-10, pp.101 113, 1990.

33) H.W. Heinrich, D. Peterson and N. Roos : Industrial Accident Prevention, McGraw-Hill, pp.20 28, 60 $\sim 66,1980$.

34）井上威恭監修：FTA 安全工学, 総合安全工学研究所 編，日刊工業社，pp.1 57，1981.

35）近藤太二：災害分析における欠陥関連樹法の適用，安 全, No.1, pp.22 27, 1972.

36）W.P.ロジャーズ (新田勝通訳)：システム安全性工学 入門，鹿島出版会，1974.

37）鈴木芳美：CTA を用いた災害分析法について，労働 省産業安全研究所技術資料, RIIS-TN-83-5，1984.

38) W.G. Johnson: MORT Safety Assurance Systems, National Safety Council(USA), Marcel Dekker, Inc, 1980.

39) R.J.Smillie and M.A. Ayoub: Accident Causation Theories: A Simulation Approach, J. of Occupational Accidents, Vol.1, No.1, pp.47 68, 1976.

40) F.E. Bird, Jr. and G.L. Germain: Damage Control, pp.11 66, American Management Association, 1966.

41) W.E. Vesely: Engineering Risk Analysis, In: P.F. Ricci, L.A. Sagan, C.G. Whipple, Technological Risk Assessment, Martinus Nijhoff Publishers, pp. $49 \sim 84,1984$.

42）泉太一郎：リスク評価に関する一考察（その 1 〜 の
7 ), 損保企画, No.331 339, 1987.

43) G.J. Briscoe: Risk Management Guide, SSDC-11, Energy Research and Development Administration, 76-45/11, 1977.

44）中村林二郎：安全性の一考察（I）（危険性）, 安全工 学, Vol.20, No.3, pp.120-126, 1981.

45）斉藤玄人・大石邦雄・関根和喜：災害事象生起のフラ クタル的特性, 第19回安全工学シンポジュウム講演予 稿集, pp.75-78, 1989.

46）花安繁郎：災害発生時間による安全水準の評価につい て, 土木学会論文報告集, 第301号, pp.105 113, 1980.

47）花安繁郎：建設工事労働災害の被害強度・規模特性に 関する統計分析，土木学会論文集，第462/IV-18, pp. 131 140, 1993.

48）花安繁郎：建設工事における労働安全問題，日経 コンストラクション，第90号，pp.95〜112，1993.

49）川崎健次・田坂隆一郎・安井英二：土木工事における 労働災害資料の統計的分析, 第 8 回安全工学シンポ ジュウム講演予稿集, pp.5-8, 1978.

50）花安繁郎・鈴木芳美・西本徳生：工事中の労働安全性 評価と対策, 労働災害（構造物のライフタイムリスク の評価：第5章)，土木学会編，pp.144〜180，1988.

51）前田幸雄：構造信頼性とヒューマン・エラー，第14回 安全工学シンポジウム講演集, pp.43〜 48, 1984.

52）山本正明：構造物の安全性ととヒューマンエラー，土 木学会論文集，第355/VI-2，pp.134～139， 1985.

53）鈴木基行・高橋美昭・尾坂芳夫： $\mathrm{RC}$ 構造の安全性に及 ぼす人為的過誤の影響, 土木学会論文集, No.451/V -17, pp. 159 168, 1992.

54）産業安全研究所：産業災害情報データベースに関する 調査矿究報告書, 産業安全技術情報データベース委員 会, 1986 .

55）鈴木芳美・前田豊：労働災害調査資料のデータベース 化, 安全工学, Vol.28, No.4, pp.239 243, 1989.

56）鈴木芳美：安全のためのデータベース（安全活動に役 立つデータベースを), 安全, Vol.41, No.5, pp.8〜13, 1990.

57）鈴木芳美：建設工事労働災害に関するテキスト情報の 解析, 労働省産業安全研究所究報告, RIIS-RR-92-10, pp. 103 116, 1993. 